\title{
Longings from the Bottom of the Boat: Re-assessing Transformation in a Polish Sailing Resort
}

\begin{abstract}
This article introduces an ethnographic discussion of the afterlife of a legendary sailing tavern, the Zęza (The Bilge), in a small sailing resort in the Masurian Lake District, Northeast Poland. The existence of the tavern falls within the high times of post-socialist "transformation": it worked from the 1980 s to the early 2000 s, when it was re-located as part of re-designing the marina. The author suggests that the discourse of longing for the community and atmosphere in the old tavern has mobilised members of the sailing community, local entrepreneurs, and, most recently, new investors to revisit and subvert the locally realized version of touristic "transformation". The article analyses the debate of longing, loss and exclusion among the sailing community, then moves to introduce the owner of an emerging local enterprise that re-appropriates the values of the old tavern community for creating a new touristic alternative and self-gentrify. A closer look at the evolving local gastronomy provides insights into the compatibility of diverse sets of values in a shared place of longing in contemporary Poland.
\end{abstract}

Keywords: Tourism Critique, Transformation, Longing, Sense of Place, Sailing, Local Entrepreneurship, Poland, Masuria 


\section{Introduction: Descending into the bilge ${ }^{1}$}

There are places of global modernity which have become universal places of longing, writes David Picard (2011: 1). Their effigies are enthroned on billboards on top of skyscrapers and on advertisements in metropolitan underground railways. These places exert a particular, irresistible magic on people, affirms Picard tracing the charms of garden Eden to the French island La Réunion. They are "places out there of eternal sunshine, of serenity, with white sandy beaches fringed by turquoise water and a bright blue sky." (Picard (2011: 1)

But there are other places of longing too - ones, which will never find such a prominent, pleasant location. They become places of longing for the simple reason that they do not appeal to everybody and at every given moment, but, instead, acquire meaning for a particular group of people and at a particular moment in time only. They come into existence in self-furnished nooks and corners, brimming with daydreams and filled with old things, as Gaston Bachelard (1994 [1985]): 142) describes them in his tractate on the poetics of space. Alexei Yurchak (2005: 151-154) for example finds such a niche in the Soviet basement boiler rooms, which were haunted by intellectuals and hobby musicians, most of them in the political opposition. Such places can take on a subversive character and serve as an alternative to domineering discourses of the present or as a framework for diverging projections for the future. They develop in the protective spaces of small communities with their own language and history, their value regimes, traditions, imaginations and utopias. Such places do not only unfold in tourist contexts, but can be enhanced by them even. As Richard Ocejo $(2011,2014)$ shows over the course of his study about the Lower East Side in Manhattan, especially in the course of gentrifying processes of "upscaling", where some parts of the population are starting to feel excluded from their neighborhoods, such alternative places of longing and the nostalgic narratives that constitute them can take on an important role in challenging hegemonic aesthetics and value regimes.

The sailors' tavern "Zęza" in Northern Masuria is such a place of longing of this second category, deeply anchored in a local tourism culture. Its particular magic works on a small cultural community of Polish sailors and local residents to the surroundings of the village of Sztynort. The translation of "Zęza" is bilge and describes the lowest part of the boat, in which all the dirty water accumulates.

1 This article is an updated and translated version of Die alte Zęza: Vom Mekka für Segler zur raubeinigen Ressource für Tourismuskritik, published in 2019 in Eden für jeden? Touristische Sehnsuchtsorte in Mittel- und Osteuropa von 1945 bis zur Gegenwart, ed. B. Hoenig, H. Wadle, Göttingen. I thank Christa David-Wadle for her thoroughness, empathy, and generosity in translating this piece. I also thank my peer reviewers, to the editor, Magdalena Sztandara, and to my colleagues at the Institute for Anthropology and Ethnology, notably Jan Lorenz, for their comments and feedback. This article would not exist without the many conversations, the hospitality and the trust of my research collaborators in Sztynort and surroundings. 
The name symbolizes the intimate and rebellious character of a place that has become a moral benchmark for criticism of tourism modernity and gentrification in Masuria and of transformation in Poland more broadly. In the place of longing of the "Zęza", touristic imaginations and local myths merge with processes of remembrance and an alternative historiography of transformation.

In this article I am arguing that, on the backdrop of privatization and gentrification processes in the tourism landscape of the Masurian Lake District in Northeast Poland, recollections about the former sailing tavern Zęza have become a source of identity for tourism communities and entrepreneurs. They have further been appropriated and mobilized locally and used as an empowering site of longing, capable of normalizing counternarratives of post-socialist transformation and providing a moral backing to new local entrepreneurial practices. This article contributes to the endeavor of developing the conceptual framework of tourism sehnsuchtsorte, tourism sites of longing, in the particular context of Central and Eastern Europe (Hoenig, Wadle 2019). Tourism sehnsuchtsorte draw our attention to diverse, transnational geographies of longing and to the complex politics of affect connected to these, exploring both subversive and loyal trajectories that are enacted through placing sehnsucht. The concept is thought as a theoretical encouragement to draw connections between different regimes and histories of social and spatial (im)mobility and to explore cultural imaginaries and communities of longing that come with them. The story of the Zęza also presents us with a struggle over the ownership of and access to the symbolic capital of a transforming tourism culture - of sailing tourism - in an economically deprived and culturally marginalized area of Poland with a complex history of diverse longings - the Masurian Lake District.

Thus, the place represents a space of dialogue between current debates of anthropological tourism research on tourist imaginaries (notably Salazar, Graburn 2014) and the discussion about cultures of remembrance in Europe (Macdonald 2013), particularly in formerly Socialist states. Since Svetlana Boym's (2001) influential oeuvre on nostalgia, research has particularly concentrated on those contemporary discourses of remembrance, nostalgia and longing in Central- and Eastern-European societies, which concern a Socialist past (such as Hann 2012; Heady, Miller 2006; Nadkarnyi, Shevchenko 2014; Todorova, Gille 2010). The term "Ostalgie", meaning practices of longing for the past GDR, is a prominent example of such discourses of longing in a society and their political moralizing (Ahbe 2005; Bach 2014; Berdahl 1999). But also the mobilization of various memories and longings of pre-Socialist pasts, particularly of former national territories, raised growing interest in the international research community. In the German-Polish context that also includes the area of Masuria, there are two forms of longing for pre-socialist imagined pasts which find the particular interest of research: "Heimweh" or "tęsknota" for the national East that was lost in the war. In the first case it is the longing for the lost "Heimat" in Germany's former East 
(cf. the works of Burachovič 2002; Fendl 1998; Meindl 2019; Verschaeve, Wadle 2014), in the second for the former eastern parts of Poland, the "Kresy Wschodnie" (Chrzanowski 2001; Cynarska 2009). Contrary to those historic periods, the nostalgic remembrance of the years of transformation and the early years of postsocialism has yet hardly been subject to research or been analysed as to its meaning for today's societies in Central and Eastern Europe.

This early post-socialist nostalgic debate can be framed within a discursive framework of gentrification. Redistribution of land and real estate, often connected with the hope of enhancing value through attracting a wealthier, consuming clientele, have been at the heart of post-socialist transformation processes in Poland (such as: Gądecki 2012; Jakoboczyk-Gryszkiewicz et al. 2017; Marcińczak et al. 2013). Tourism has been globally identified a major motor for gentrification tendencies, both in urban and rural environments (cf. Gravari-Barbas, Guinand (eds) 2017; Hines 2010; Sequera, Nofre 2018). If turning to tourism to develop areas is one aspect, the other is the upscaling of existing tourisms spaces has become a focus point (Vail 2004) - one being the case of backpacking, another the gradual transformation of socialist tourism infrastructures (Chrenka, Ira 2011; Ghodsee 2005; Verdery 2003). This case of sailing tourism in the post-socialist context of Masuria furthers insights into the gentrification of pre-existing tourism infrastructures and related exclusions. It also continues recent work on gentrification that emphasizes the active role of residents in opposing strategies of exclusion and displacement (Arkaraprasertkul 2018; Brown-Saracino 2007, 2009), for instance through self-gentrification (Chan et al. 2016) or the subversive use of alternative authenticities via nostalgic narratives (Ojeco 2011, 2014; Berliner 2012). Postsocialist societies are currently undergoing a phase of reflection, in which hopes connected with, and first experiences of the drastic changes are compared to the present situation and put up for discussion. In my analysis I understand this phase of renegotiation as late post-socialism. On the empiric basis of these renegotiations in late post-socialism the following considerations seek to better understand longing as a moral and an affective resource of societies in transformation.

This case study is founded on seasonally multi-sited ethnographic and archival fieldwork (Marcus 2011) in the years 2010 to 2019 in North Masuria. From 2010 to 2011 I spent 13 months as an ethnographer in North Masuria, looking at transformations of touristic cultures and encounters in and around Sztynort. In the summer months I accompanied Polish sailing trips and German groups of visitors and from autumn to spring, I found accommodation with a local family in Sztynort, and got to know the local village community with its roundabout 25 families. Since the completion of my doctoral thesis I have travelled to North Masuria several times every year on a regular basis to meet old and new partners of conversation, look at new developments and discuss the results of my research with the researched communities. This article also draws on newspaper article that I researched in the museum archive in Węgorzewo and I draw on online 
resources such as visual media or blog entries published by individuals or conversations and chats. In summer 2019, I discussed and revised an earlier version of this text with Iwona, the local entrepreneur who will appear as a central figure later.

As part of Warmia and Masuria, the Masurian Lake District is one of the areas in Poland that, from a socio-economic stance, has suffered from structural disadvantage, and that, from a cultural stance, has not only been marginalized since the breakdown of socialism, but well before, since after World War II, when it became a new part of Poland. Ideologically framed as "re-gained territories" to the Polish nation, its multi-ethnic pasts and traumatic history of population exchange was largely silenced. New populations were deprived of narratives of belonging, and former populations remained largely behind the Iron curtain, they were unwanted both in post-war Germany and in their former heimat. Anyone writing about tourism in the Masurian Lake District, an area of Warmia and Masuria in the Northeast Poland, is thus almost destined to address the issues of longing and loss, about nostalgic lament over lost pasts, homelands, natural environments, and senses of belonging (cf. the works of: Grochocka 2015; Kossert 2006, 2007, 2009; Łukowski 1998, 2002, 2005; Mai 2005)

The identities of rural communities of Masuria are doubly untypical for local populations in a popular tourism destination: firstly, because as result of post-war migration processes, they lack a generational continuity and have been presented as society "without tradition" (Lukowski 2005), secondly because many rural residents do not historically represent agrarian, pre-modern rurality, but rather a post-industrial workers of Agricultural State Farms, a socialist farming model, that was suited to adapt ample former gentry estates in former East Prussia to collective farms (Szpak 2005: 19-29; Tarkowska 2000a).

Practices and perspectives like described in Tomasz Rakowski's ethnography (2009), in which he physically enters the ontological groundings of degradation and disempowerment of left out communities in Poland are part of the reality of Masuria, too. For the past years, in Sztynort, the majority of residents has lived on a minimal wage, a meagre state pension, benefits, or sporadic incomes earned abroad. There is a high dependency on local employment in tourism and little alternative to it, what give employers a strong hand over their workforce. Individuals I spoke to, have in the past decided against taking on jobs in nearby towns, since the cost of commuting would have be too costly for people to "afford the jobs". Apart from tourism and work in the local forestry, work migration is another common strategy for making a living in the sparsely populated, economically deprived area. In the biographies of many individuals I spoke to in and around Sztynort, both work in the tourism sector and work abroad in Italy, Germany, the UK, Ireland, Holland, Norway, France, Mallorca, the USA, Canada, Australia, or to the urban Poland - Warsaw or Gdansk - are present. 
Sailing, both as a sport and as a tourism activity, looks back on a long tradition in the Masurian Lake District. As early as in East Prussian times at the beginning of the $20^{\text {th }}$ century sailing clubs were founded and first regattas took place. The region became a spot for sailing enthusiasts. After World War II and the assignment of the regions to the Polish State and particularly from the late 1960s onwards, the region turned into the most important sailing area of the People's Republic of Poland (Wakar: 87). This was partly due to the picturesque character of its nature, but there were also other reasons: sailing on the sea in Poland, particularly on the Baltic Sea, represented a risk for the state, the risk of its citizens escaping into non-communist countries. This is why only well selected, trustworthy groups and individuals were authorized attendance to sailing trips on the open sea by the state (Urbańczyk 2013).

The lakes in Masuria, cut off from any access to the sea, were considered to be "safe" in this respect and thus developed into a destination for sailing departments of universities, scouts, state firms and rural collectives. ${ }^{2}$ Sailing became an integral part of the regional identity and served as the central stage for the transregional touristic encounter of sailors from Poland (and even from other places) with equally passionate local sailors. To this fluid community, sailing culture on the lakes in Masuria is common ground.

The transformation of a predominantly state-owned, non-commercial and nationally organized tourist sailing business into a predominantly private-owned, commercial and internationally open tourism business since the 1990s gave rise to important negotiations about the character of the sailing community and its socio-cultural stage of "Mazury": ${ }^{3}$ Its values, esthetics, and accessibility have since changed and require communal negotiations. The former sailors' tavern Zęza, a tourist institution from the times of transformation, holds an important part in these negotiations about the identity of the sailing community in Masuria. It allows us to discover paradigms of postsocialist transformation and understand mechanisms of how currently the building of community works.

The following section introduces vernacular historiographies of the transformation of tourism in the village of Sztynort in Masuria from the 1990s onwards, after which also the sailors' tavern fell victim to the restructuring of the harbor. The further part then considers the moral reinterpretation of the tavern and introduces a local entrepreneur, who becomes a self-gentrifier by appropriating nostalgic discourses of earlier sailing communities and by designing an alternative to investor-led gentrification. This section will be followed by a concluding discussion about limits between this local alternative and the prevailing, clean and easyto-consume, modern tourism in Masuria.

2 This information was obtained in interviews in 2009 with the team of the tourism information centre in Giżycko, in October 2010 with a sailing instructor and former scout leader from Giżycko and in August 2016 with the former directors of the Sztynort sailing centre.

3 The Polish term "Mazury" has a historically forged connotation that diverges from the German term "Masuren", see Agnieszka Grochocka (2015) for the literary myth of Masuren. 


\section{Old Zęza, New Zęza: Longing for a different kind of transformation in Masuria}

It is the third day of a 10-day sailing trip round the lakes in North Masuria for twenty adults on five boats, who today are capturing the first wind in their sails. ${ }^{4}$ The course is organized by a young business from the area. It has been booked by students and professionals from the urban centers in Poland, but also from Great Britain and Germany, all of whom of Polish nationality. The destination of the day is Sztynort port, to many a highlight of their sailing trip through Masuria. A particular favorite there has always been the sailors' tavern Zęza, which was opened in the early 1980s. "The tavern in port Sztynort is our favorite in Masuria! There's always something on, there's live music and people dance until dawn", 21-yearyoung sailing instructor Michat ${ }^{5}$ boasts to his crew. He is a student of the prestigious Poznań Business School, has been a regatta sailor since his earliest teenage days and spends the summers working in sailing tourism.

In Sztynort the transformation of the system and redistribution processes in the tourism sector become tangible. After the War Sztynort had first of all been chosen as the location for the head office of a State Agricultural Farm. ${ }^{6}$ In the context of the Socialist modernization of the 1970s, it was decided to create a sailing center for the offspring of agricultural workers. These were the beginnings of the contemporary tourism profile of the village, which henceforth became a destination for the Polish sailing community. In the 1980s the responsibility for the further touristic development and the village management was handed to one of the first Polish joint ventures. ${ }^{7}$ In that time a national sailing center with a hotel and surrounding agriculturally exploited lands developed, where every year clutches of children learned how to sail. ${ }^{8}$ Since the 1990s both the port and a considerable part of formerly communal buildings and the surrounding open fields have

4 Ethnographic documentation from June 2010 during participant research in respective sailing course.

5 Pseudonym: names and personal details in this chapter were changed for the protection of the informants.

6 State Agricultural Farm (Państwowe Gospodarstwo Rolne, PGR) - this was a type of collective farming in the Polish People's Republic inspired by Soviet sovkhozes or East German Landwirtschaftliche Produktionsgenossenschaften (LPG) that was often introduced in the place of previous country estates, particularly on former East Prussian territories.

In 1980s Poland, first capitalist experiments were taking place and members of the political and economic elites were involved in creating corporations and joint ventures, mostly with publicly controlled associate stake holders (Piotrowski 1988).

8 This information was obtained in numerous talks with former staff and villagers and an extensive interview with the former director of the sailing center. Special thanks to Maria Zarembska, Marianna Dacko, Jurek Dacko, and Jerzy Litwinienko for their help with reconstructing the social history of the place. 
repeatedly experienced a change of ownership, ${ }^{9}$ in the course of which projects of modernization remained more or less fragmentary: as a result, locals felt alienated and historic buildings partially fell into decay. The port, however, was modernised and completed with its own guesthouse. It thus gained a reputation as Masuria's most modern pleasure port complex. Unused, "unnecessary" buildings and such kind buildings that did not fit in with modern aesthetics, also those which would have required particular efforts of renovation, were pulled down or, like in the case of the protected monument of the castle, left to decay. The area of the village that could possibly be exploited for tourism was thus reduced to a bare minimum, the other buildings were put to new uses and redeveloped. ${ }^{10}$

This was also the fate of the port tavern Zęza, the transformation history of which I was confronted with again and again throughout my ethnographic field research in Masuria between 2009 and 2011, and my regular returns until 2019. Until 2018, a Warsaw based joint stock company organizes the tavern in the summer months as part of the complex of the port. The Zęza which I get to know is located in a hangar, the well-tended interior of which looks deliberately cozy and like the interior of a huge sailing boat; the atmosphere is obviously adapted to what customers might wish to see. Drinks are sold at Warsawian prices and the waiters and waitresses are professional seasonal workers in uniform work attire, young adults and students from the region. Nearly every evening there is Polish live shanty music until in the early morning hours, that is also what the website of the tavern promises. To all those, who have made their individual peace with this new tourism aesthetics and see themselves reflected in it, this version of the Zęza has become their local comfort zone. Immediately next door are the modern, ample and free sanitary facilities of the port, at the time a unique selling point in the touristic infrastructure of the region. With this arrangement and the port-owned supermarket, a pizzeria, a fish roasting stall, a small shop for sailing accessories and free internet Sztynort port is a vision come true of modern sailing tourism in today's Masuria. Not everybody I have talked to is as enthusiastic about today's Zęza as our young sailing instructor Michał, who has been sailing in Masuria for only a few years yet, eyes expensive sailing anoraks and hopes for a safe job in the thriving Poland after his studies. Many, however, long for a different place: for the old sailors' tavern Zęza, before it was redesigned and with its former socio-cultural and material character. To them, the "old" Zęza appears to be a lost place. While, for various reasons, they feel excluded in the new Zęza, the old Zęza continues to exist in their remembrances and stories. Shelly Hornstein

9 This can be retraced in archival newspaper articles, which were accessed in the Archive of Muzeum Kultury Ludowej, Węgorzewo. I am grateful to archivist Wanda Pisarek for her help: n.n. 1991; C.J. 1992; n.n. 1992; Dągowski 1995; n.n. 1995; Kwiatkowski 1996; Tomaszewski 1997; Łapo 1997.

10 Information from talks with current and former locals of Sztynort and from the local press: n.n. 2000: 9. 
writes about the community of Jewish exiles in the United States that some places that are lost or that we have had to leave can continue to exist elsewhere or in different forms - virtually or in new materiality. Such places, she writes, might first seem to be lost, but in the end, they are places re-discovered (Hornstein 2011: 148). The texture in which lost places continue to exist, talk about power, access to resources, about inclusion and exclusion.

"Do you know the history of Sztynort a little, Hannah?", a regional tour guide asks me in May 2011, in a meeting with a group of guides from nearby towns of Giżycko and Węgorzewo in the Zęza. Expecting a sketch of the last 500 years of the village, including the colonization through the Teutonic Order and the terror and turmoil of World War II, I curiously wait for his historic narrative. But the story most important to him in this very moment only reaches back into the 1980s. Sharon Macdonald (2013: 15-17) holds the thesis that current European communities define themselves to a relevant degree via their memory cultures, a phenomenon she calls "past-presencing". That is why the unexpected turn of the history of Sztynort, as the guide tells it, is all the more fascinating:

You know, where we are now, that is not the true Zęza. The true Zęza was over there, in a cellar, where now the hotel is located. The Zęza was a sailors' Mecca, they all came there, to sing, to drink, to dance.

The other guides euphorically agree with their colleague. His history lesson to my attention at the same time underscores their common values, recalls memories. They recount that some of them formerly worked as sailing instructors or skippers on the lakes. The old Zęza to them represents an ideal alternative to the experiences of modernization, the drifting apart of society and the commercialization of culture. One of the guides recalls the social continuity of sailing tourism in rural Masuria before the use of the telephone and the internet: the Zęza was used as a reliable place for members of the sailing community to meet again a year later at the same time. I find more traces of the discourse on longing for the lost Zęza elsewhere, too: in virtual discussion fora of the sailing community and in archives since the late 1990s. ${ }^{11}$ The discourses of a growingly marginalized part of the sailing community of Sztynort in cyberspace allow fragmentary insights into complex nostalgic feelings framed in the modernization processes of the sailing resort. Here, too, the longing for the "old" Zęza creates a discourse running against the mainstream evaluation of the effects of transformation. In stories it appears as the place where one would meet "true sailors", adventurers, story-tellers, long-bearded guys, drunkards. Who went down to the Zęza, they say, often stayed

11 Discussions on touristic sites such as: campeteam.pl; zegluj.net; sailforum.pl; mazury.info.pl; gastronauci.pl (examples); in Google-groups: <http:/groups.google.com/group/pl.rec.zeglarstwo>; on the Video Plattform youtube.com or on private blogs: blog.fafara.net 
there for several days. A rough place, squalid and hard to bear. ${ }^{12}$ A place the sensuality of which you had to submit to, you had to melt into: thick smoke, beer, sweat, alcohol. Communal shanty singing in several parts, dancing on the tables, drinking to unconsciousness. For food there were the best pierogi in the world. ${ }^{13}$ Such contributions in fora of discussion on the internet, in which sailors communicate, document the development of a trans-local und virtual emotional discourse of longing revolving around the Zęza. The Zęza is stylized there as a symbol of a soimagined golden era of sailing tourism in Sztynort and of the community feeling created there.

The following quote very clearly betrays the feeling of being excluded from modern tourism in the shape of the new Zęza. Bereft of part of their history and identity, sailing tourists in the internet turn into historians of transformation. The eerie transformation of the Zęza becomes a metaphor for the eerie experience of transformation and loss of place, the tourist place of longing, the Zęza, turns into a social place of longing: "To me it seems, as if the end of Zęza marked the definite transformation of Sztynort, there is no longer any place for us in the new Sztynort. There is only place for those with captain's hats and their fat yachts." ${ }^{14}$

The "new" Zęza is friendly, smoke-free, uncomplicated, animated, easy to maintain and easy to consume. The development of the legendary sailors' tavern points at the vulnerability and finiteness of a community of tourist culture and values. Thus, a new, undefined "we" comes into existence of those who are excluded from the neoliberal modern sailing tourism, the "new" Sztynort and the "new" Zęza. Locals who can neither afford the new place nor participate in the creation of hospitality in the tavern. Or "old school" sailors, whose contribution to sailing tourism is no longer welcome. Where in earlier times songs and guitars of the sailing community were the center of life and interaction in the old Zęza, in the meantime shanty-singing is organized by the management as an official evening program by paid (yet generally recognized) acts.

Apart from this particular marginalization there is also a feeling of vilification of sailing per se: The Zęza has to move out in favor of a hotel jazz bar to a low-

12 This narrative can be found in the contribution of the user Dmofran of $5^{\text {th }}$ March 2005 on the platform zegluj.net, in which he writes: "And I remember the 80s in Sztynort, when the Zęza was such an awry tavern that really only the most courageous sailors showed up there. But what an authentic atmosphere was to be had!" (pl.klimat) net/forum_zeglarskie/viewtopic.php?t=489> "A guitar player at each long table, cigarette smoke, you could have hung a sickle in it, loud, full to the brim, with a unique atmosphere. We were sitting on tree stumps, the tables were simple wooden boards. There was even a time when beer and wine were sold through a net (the bar was protected by a net), that was what it was like in 1987/88" (translation from Polish by HW) $<$ http://www.zegluj. [This link is no longer active, the discussion was recorded in the archives of the author].

13 Remembrance from a private blog from $10^{\text {th }}$ March 2010 under the title "Sztynort Reaktywacja”, http://blog.fafara.net/index.php/2010/03/13/sztynort-reaktywacja/ (access: 30.01.2017).

14 Translation of a discussion on the online sailing forum: <http://forum.zegluj.net/ viewtopic. php?t=489>, [Link no longer active, discussion in the author's archives]. 
grade building. Many sailors see their cultural self-concept as traditionally privileged, "better" tourists undermined by this new, economic priority. This is also the view of sailor and internaut mnowak8 in the end credits of his film about the sailors' tavern on YouTube:

The Zęza tavern was an iconic tavern for sailors in Masuria. It has existed for many years in the vaulted cellar of the guild building in Sztynort. It existed until 2005. In 2006 the former Zęza was turned into an exclusive wine bar. The new Zenza [sic! $]^{15}$ was opened in a hangar in the port. Unfortunately, it is impossible to move the magic of a place.

With the title "The Tavern Zęza in Sztynort, A Short Film on the Atmosphere in the Lost Iconic Tavern" the author in his middle thirties, a journalist and a local politician in Silesia posted the fragment of a family video from 1993, which had been filmed in the old Zęza, on the platform. His obituary makes us visualize the political, socio-critical potential of tourist longing (in this case nostalgic longing). Replaced by a wine bar and translocated to a different building the Zęza, with all of its roughness and brusqueness, with its inescapable community, is stylized as a symbol of a lost Polish society, a paradigmatic refuge from the redistribution of tourism spaces.

Ocejo's work about the Nightlife in the Lower East Side in Manhattan shows surprisingly many parallels with the social complexity of loss and longing around Sztynort's Zęza and provides a possible reading to it. Ocejo suggests that the narrative of loss is particularly pursued by a group of who he terms "early gentrifies", individuals, who moved to a deprived area, after which the area entered a revaluation process. In the lamentation narratives of these "early gentrifiers" for the earlier nightlife of the neighbourhood, Ocejo finds a liking for worn-out settings, and a tendency to construct authenticity through a roughness, grittiness, unkempt nature of pubs, comparably to how the old sailing tavern is portrayed by the first participants of commercializing sailing tourism culture of Sztynort. If, as Ocejo notes, early gentrifiers in Manhattan critique a loss of the creative and participatory character of nightlife, as they recall it from poetry readings and art exhibitions, in favour of bland consumerism, the nostalgic discourse on the Zęza, works in a similar fashion, including memories of singing together, jamming on the guitars, dancing on tables. Respectably, he also notes the recalling of the idealized protagonists of such former nightlife settings - old men telling stories, very much like the so-recalled old sailors in the Zęza.

Currently, in the tourism sector of Masuria, places that were once created by a cultural (tourist) community are pocketed by large investors and sold as a readymade product to a newly defined and limited (tourism) community. Thus initiated processes of social redistribution, societal marginalization and cultural disowning are hard to document as concerned groups are a fluid, multilocal community

15 Here mnowack8 mocks the orthography of the tavern in "Zenza". 
of sailing tourists, staff and locals, whose slow disappearance or exchange will scarcely be noticed.

When the generous terrain around Sztynort which was exploitable for tourism purposes was declared up for sale in the 1990s, the role of the residential population changed dramatically. In the beginning of the sale phase locals were portrayed publicly in the media, by politicians and investors, as good workers and capable hospitality managers, who would doubtlessly find jobs in the tourism business and would be welcome there. In this time local entrepreneurs, on their own initiative, filled in the gaps in the tourism business that had opened as a result of the liquidation of the holiday center and of the delay of its sale. The situation changed radically, when the investors also made a bid to the town council for the residential locales in Sztynort. As employees of the state farm and later of the sailing centre in the Polish People's Republic, local residents did not own their housing privately. The town administration suggested that all residents move to the outskirts of the village, which provoked the communal resistance of a majority of the village population, as the proposed alternative to the houses with their gardens was a low-grade, narrow accommodation. In a ten-year-fight of lobbying for their rights, the inhabitants finally succeeded in winning the right to buy their flats as property. This, however, created extreme tension with the new, monopolist, employer in the village, who for a certain time stopped employing people and even barred locals from entering the port precinct. What is more, investors and politicians started stigmatizing the villagers: Sztynort was described as a place in which "the population was vegetating", "drunkenness, theft, rows, poaching, and timber theft" (Łapo 1999: 9f) were said to be happening on a daily basis.

This contorted description looked at a reality that had been provoked by the town council and the investors themselves: the arbitrarily produced unemployment and the lack of perspectives and participation, both produced by redistribution, often pushed people into depressions, abuse of alcohol and distrust of each other. ${ }^{16}$ Michael Herzfeld (2006) suggests that the large, emptied spaces in urban tourism resorts and heritage sights, which he ethnographically studies in Rome, on the Island of Crete and in Bangkok, are evidences of hegemonic regimes of what is understood as "civilization" and materialized expressions of Western dominance. Governmental agendas of gentrification produce a cleansing from undesired, stigmatized, alterity, a process he terms "practical orientalism / practical occidentalism" or "practical essentialism" (Herzfeld 2006: 131). The processes in Sztynort may be read in Herzfeld's terms as the latest story of "practical essentialism" in Masuria - of "de-cluttering" and "tydying" the touristic rural Masuria from the orientalised, "stigmatized brother" (Buchowski 2006), from communities of Post-socialism that had previously been systematically socially degraded (Rakowski 2009).

16 This change was reconstructed through newspaper articles of the local press of Wegorzewo from 1991 to 2001 and through discussions and interviews with locals. 
Such cases can be witnessed since the 1990s in other communities of Masuria which are attractive for tourists. Many communal administrations attempt to appeal to an upmarket class of tourists by selling large areas, historic buildings as well as former state holiday infrastructures to international investors and thus to generate new tax income. The unfulfilled desire of many tourism resorts in the past decade has been to attract exclusive hotel and wellness area to their towns in numerous cases investors withdrew from their contracts on short notice or did not respect previous arrangements with the communes. Where hotels and holiday resorts were built, the hopes of the municipalities were not necessarily fulfilled: in the holiday destination of Mikołajki, which boasts the only five star hotel in Masuria, local business people hardly profit from the wealthy guests, who have no reason to leave the resort with its comprehensive offer (Derek 2007). In other places the quality of life of locals as well as of the less wealthy tourist population suffer as a result of the delimitation and privatization of areas that were earlier used for local recreation: gates bar the access to former beaches or even the vista of the lakes, which are turned into exclusive port resorts. This does not surprise as a story in a global narrative of tourism developments and gentrifications, but it must be seen on the background of a preceding socialist reality, its accompanying social contract, and the expectations of a post-socialism that benefits society as a whole. The longing for a different transformation, a different tourism in Masuria, crystallizes in a place like the Zęza, becomes tangible in the longing for a place that existed in the past. Knowledge about the communal past of the Zęza keeps it present as a place of the myth of good life and community. Internalized and shared with others through storytelling this knowledge will also set free forms of moral resistance and cultural self-confidence. Nostalgic narratives for the "old" Zęza cultivate and renew moral values of those members of the tourism community who feel pushed aside by processes of gentrification of existing tourism structures, a processes similarly observed by Ocejo (2011) in Manhattan. This is how resources for change and alternative local development come into existence.

This argument is further explored in the story of Iwona, a businesswoman, born in Sztynort in the 1980s. The development of her small business, first an off-license bar and later a fish and chips restaurant with homecooked meals, and her clientele presents us with a story of belonging and identity in rural Masuria. It tells us about the struggle of a third and second generation society of post-war domestic migrants (Łukowski 2002, 2005) and post-socialist internally marginalized (Buchowski 2006; Tarkowska 2002a), seeking authority as local hosts and claims over authenticity, and opposing further marginalization. Iwona engages with the nostalgic narratives of the early post-socialist sailing tourism and the Zęza and complements them with its local interpretations to craft her own moral discourse as an entrepreneur in the hospitality sector. Appropriating this discourse a allows her to re-claim the local social capital of hospitality and pursue her own path of 
what can be termed after Chan et al. (2016) "self-gentrification", becoming part of the different, gentrifying tales of the tourism resort.

\section{The "Old Zęza" as moral and emotional resource for alternative hospitality}

If only I could, I would dig out a cellar, like the Zęza in the old days. With M. [the former locally based lease holder of the tavern - H.W.], everything was more family-like. I don't want the village to be lost. What they [the management of the port] are doing here, destroys our village,

Iwona says in a firm voice. ${ }^{17}$ She is defying the cold rain of this first weekend in May in her kiosk, made from corrugated metal with the inscription "Alkohole Swiata" (Alcohols of the World), waiting for buyers from the port or, more rarely, from the village. For two years the young woman in her mid-thirties has been doing business as local trader in Sztynort's otherwise monopolistic tourism landscape. Apart from a corner shop in a former construction trailer and a shop for sailing fittings, at that moment all other commercial tourist offers are in the hands of a Warsaw-based real estate group. It is therefore not an easy job for Iwona to economically profit from local tourism. However, the old Zęza has won an important meaning in its fight against this resistance for the sole trader and her business. It is in this crisis that the vision of the old Zęza helps Iwona. For her it represents the moral construct of a better Sztynort, refers to an imaginary community of sailing tourists and locals and becomes a cultural and social inspiration for the founding of her new business in the village.

Iwona grew up in Poland's transformation process and its development towards capitalism and she made her way there. Whereas her brother emigrated to Great Britain, she tried her luck first of all in the urban Poland as a student and employee in a supermarket, then in a nearby town in a second-hand clothes shop and on her own online platform with second-hand brand clothes, and recently, starting around 2008, she worked in Sztynort as a lease holder of the local Smażalnia ryb,

17 Talk with Iwona on $2^{\text {nd }}$ May 2011 in Sztynort. Source: diary entry. Since the first encounter with Iwona in May 2011 I have met her on a regular basis between 2011 and 2019 and discussed with her local developments. I met Iwona's parents as early as December 2010, when I paid a visit to their house in Sztynort. I have also talked with them on a regular, repeated basis after the long discussion I first had with them. Between 2010 and 2019 I had the opportunity of witnessing the development of Iwona's tourism business over the years. My ethnographic observations also comprise encounters and discussions with sailing tourists, travel groups from Germany and other locals. The following paragraphs are fed by discussions and observations which were recorded in the form of diary entries, sound recordings and transcripts of interviews. In Summer 2019 I revised my notes and the article with Iwona and her family and included her feedback in this version of the article. 
the Polish version of a fish and chips shop. When a controversy arises between her and the port management, the lease agreement is no longer renewed.

Stories about the Zęza and later the longing for the past and golden times of the tavern accompanied Iwona's childhood and youth. Her father once worked in the tavern, he enjoys talking about that time. As tenant in the Smażalnia ryb she also often listens to the tales of her sailing clients about the old Zęza. Her idea of reconnecting with the old Zęza, thus follows the logics of a communally developed and cultivated discourse of longing, which she takes seriously and wants to put into practice.

In this local discourse of longing, the old Zęza is not only romanticized. Locals also talk about the day-to-day problems of the tavern as a workplace: they refer to health risks of working in the tavern, starting with respiratory problems in the smokey and mouldy cellar, to long working hours and small earnings, they recall evenings, in which they were scared because sailors vandalized the place and the situation escalated violently. Former bartenders of the tavern and their family members do not silence its broader negative impact on their individual biographies also: they tell stories about how the proximity to excess and permanent alcohol consumption led some of them to alcohol abuse and addiction. One of my informants names this problem the reason for which she did not decide to continue work in the bar, and even went to work abroad rather than taking over the lease of the Zęza, as she was offered it. ${ }^{18}$ These stories exist as part of the recollections of the "Old Zęza" locally and are often enough even told without discrediting the longing for other, explicitly positive recollections of the Zęza. This suggests that if the Zęza is a condensing point of "multiple nostalgias" (Berliner 2012), those of sailing and residential communities, it locally represents a much more ambiguous place of memory, one between damaging transgression and empowering liminality that portrays the contradictive experience of early post-socialism. At the heart of the positive narrative of longing for the old Zęza stands the positive feedback of sailing tourists towards the locally-led touristic offer in the Zęza. It comes with a particular sense of a cultural community and social inclusivity shared between locals and sailing tourists. The old Zęza is recalled as a place of accepted hospitality and social proximity with the national other.

This historical memory stands in some contrast to other tourism encounters that intensified in the 1990s: early German coach and cycle tourism in Sztynort are recalled by local residents as an experience of rejected hospitality and emotional distance. Local hosts felt rejected as hosts by the German tourists' consumer behavior: To minimize expenses and time, bus tourists were often provided with a hot sausage and roll by the tour company. In the evenings only did they have their booked menu in their accommodation. Tourists on bikes had a "light" picnic for lunch and also had their "real" meal in the evening only. Whereas Pol-

\footnotetext{
18 This is the result of conversations I had between 2010 and 2019.
} 
ish sailors in the Zęza consumed gratefully, enthusiastically and self-indulgently, Germans brought their own food, never ordered a regular meal in the local gastronomy. Iwona and her mother interpreted this experience as systematically declined hospitality, as cultural distrust of the local kitchen and home-made food. Even though over the course of time more and more individual tourists stopped by for food at Iwona's, the feeling of slighted hospitality took its time for fading.

To invest in the affective relationship with sailing tourists is much easier. To Iwona, the times of the old Zęza are a central episode in the history in Sztynort, from which the feeling of identity derived, an episode which also forms the basis for her own vision of the village. During the management of the former tenant, a local single woman with entrepreneurial can-do spirit, a unique atmosphere of hospitality and community was created. In this time, Iwona feels, the complete life in tourist Sztynort was more family-like, friendlier, more intimate. This narrative is in harmony with local stories and sailors' myths. To Iwona the locally recognized historic narrative is a benchmark for the present. It clearly makes her feel that her village and the trans-local tourist village community will "go to the dogs", as she puts it, through the current tourist offer.

She wants to stop this. I can watch over the course of my research, how Iwona's business develops. She wants her place to look nice, but not luxurious. The kiosk is but a start. In the intermediate run she plans a snack bar with fresh food and a terrace. Things are not perfect, at the moment, she explains in early 2011, but they are developing. The alteration of her parents' home in Sztynort is making progress. In the upcoming season, in summer 2011, there is a caravan of older make in the family's courtyard. In it, Iwona, her parents and her aunt fry fish and potatoes and cut homemade gherkins into slices. Umbrellas, benches and tables around it look inviting. In the meantime, Iwona also has a guest toilet - if only a chemical one and not a water closet like in the harbor. For Iwona and her parents, what counts are the encounters with the sailors, the service, the quality of their food. "I do not treat people anonymously, and people appreciate it", the owner says and ads, that this is what makes the difference between her and the port gastronomy and management. Iwona longs for a future in tourism, which confers a place to her and her guests in Sztynort. Both her criticism of current affairs in the tourism business and her identification with the past of tourism motivate her. The combined effect leads the way for her business and societal activity. She never tires to underscore how important it is for her not to see her customers according to a certain wzór, pattern, ${ }^{19}$ but to rejoice their company and their repeated visits. She recounts, how in the year before guests took photos with her. We find such photos also on the Facebook profile of her business, which she quickly puts online, as she knows social media and virtual platforms from her experience with the online

19 That is the term she uses in our talk on $2^{\text {nd }}$ May 2011 in Sztynort; source: diary entry. 
shop. On Facebook, Iwona also encourages people to bring their guitars and to sing traditional shanty music under the umbrellas.

From her longing of a summery sailing community and thanks to the myth of the Zęza, Iwona develops a participative concept of a business, which overcomes economic, political and social obstacles of the place. Iwona's faith in the myth of the Zęza will not protect her from serious hurdles, but it makes her strong in her vision, bridles doubts and provides a moral legitimation in Sztynort. Iwona's parents are astonished about their children's performances and drive. "We wouldn't have the guts, where do they find the courage and competencies?" The two worked a long time for the local agricultural production company and after that for the holiday center and finished to be taken on by the new investor, she in the supermarket as a cashier and he as a safety guard. They never learnt to take the initiative, they explain to me. But they are on their daughter's side and do everything to support her. It is also because the cultural values which their daughter argues with fit in with their own moral place of longing, the Zęza, and their visions of good tourism in Sztynort. They help them against the powerlessness in face of the feeling of progressive decay of hospitality for sailing tourists in Sztynort.

"What they [the port society in the new Zęza - H.W.] serve for breakfast, that is completely improper for sailors. And they sell a ready-made soup for ten Złoty, crazy! In those times at the Zęza, there was good, home-made food, appropriate for sailors: eggs, pierogi, bigos. It was affordable for everyone", Iwona's parents tell $\mathrm{me}^{20}$ and confirm her daughter in her business activities. The described development towards the negative ultimately interferes with their local identity as a hospitable village community and deters "true" sailing tourists, whose company they appreciate, with high prices and culturally wrong food. A similar reaction to the corporate integration processes and local entrepreneurial marginalization is described by Waldemar Kuligowski (2019: 12) in his article on the local perceptions of the new motorway - modernity of the A2 motorway. There, private entrepreneurs along the country road DK 92 - hosts of mobile trucker communities - complain about the new conditions offered to their long-term clients by the new motorway infrastructures. What these two instances share is a self-sustaining solidarity with the customers that one has raised as consumers of one's particular hospitality in the early capitalist period and sometimes even before. And a nostalgic wish to return to intimacy and mutual care of this relationship.

Monika Palmberger (2008: 358), in her research of nostalgia in societies of former Yugoslavia, argues that it can be an important resource and an encouraging tool for the development of alternative visions for the future: Nostalgia "can also be seen as criticism of the present post-socialist reality and may be reflected in visions of a better future". For Iwona' parents, too, the place of longing Zęza is a moral tool; it is a certified yesterday, which gives instructions for the good sail-

20 In an interview from $9^{\text {th }}$ December 2010 in Sztynort, source: sound recording. 
ing tourism of today. Thus, the Zęza also works as an inter-generational moral place of longing in transformation society, where usually children are considerably alienated from the values and dreams of their parents.

Her parents' support for Iwona's business project is not self-evident, as it contains risks for the precarious situation of the family. The family is exposed to social envy and distrust. This is particularly obvious, as the port company is the only employer in the village and as the management of the new Zęza exerts enormous moral and economic pressure on the local population. During my visit at her parents' in winter $2010 \mathrm{I}$ learn that the port company dismissed both of them shortly before their retirement, when Iwona's new project of a snack bar with home-made food emerged. They tell me about medical treatment and that they are unwell because of the redundancy. I understand the company's reaction as a warning to the locals, which aims at containing possible competition and unwanted local developments. And what is more: It seems that the company feels menaced in its economic, probably also cultural and social claim over the interpretation of the destination Sztynort as a tourism place of longing by Iwona's alternative set of values and longings. Similarly to how Keir Martin (2009) observes it in Papua New Guinea, cultural authenticity is used differently both by marginalised and by dominant agents in Sztynort as an argument for legitimising their respective trajectories. Martin's argument that " $[\mathrm{t}] \mathrm{o}$ insist on a mono-vocal definition of authenticity is to deny the voices of those whose political situation demands an assertion of claims to authenticity measured by other scales." (Martin 2009: 540) should encourage us to take seriously nostalgic narratives as subversive strategies of earlier residents to draw up different and seemingly truer versions of their neighbourhoods and thereby challenge a commodified present of which they feel excluded (Ocejo 2011: 295). The efficiency of Iwona as a historically emerging subordinate, a subaltern, consists in the fact that she succeeds in breaking up the seemingly unanimous discourse of the gentrifying tourism modernity in Sztynort as proliferated by the port company through her voicing of longings for a tourism alternative.

Iwona attracts attention via billboards, social networking, flyers and her Facebook page. She posts and publishes self-designed site plans of her snack bar and reports about her fight against the big competitor in the port, who tries to divert the flow of customers away from her and the village street by erecting barricades and putting up their own billboards. She does enjoy the support of her family and friends, but not of all locals in the village. There is too much at stake for those employed by the port company if they show up at Iwona's bar, let alone are friendly with her. The report of a security guard confirmed that this was a realistic apprehension. He recounted how the other guards sold him out to the company management after he had been "caught" shopping at Iwona's. He was called to order for that. There are some who even perceive the young business woman as a traitor because she is endangering the only employer in the village. Iwona, 
however hopes, that other locals will follow her example. But she does not really believe this will happen, as the risks are too high and many residents remember painful experiences from the late 1990s and early 2000s with the suffocation of any business in their former Sztynort by means of the Warsaw port company: First business on the premises of the harbor was possible and there were local business owners who sold goods like fruits, vegetables, fish or souvenirs to sailing tourists. After a while the company decided in the course of renovations to ban the mostly successful sole traders from the harbor, as they allegedly were disturbing the picture of a well-tended sailing port.

While Iwona's entrepreneurial spirit will certainly motivate her perseverance and continuous fighting in the local game of David-against-Goliath for the future of her business, her set of values, connected to the myth of the Zęza, legitimizes her action. Even though she will not be able or intent to imitate it, the place of longing of the Zęza, to which she commits herself, frames her vision of a better Sztynort, for which she is ready to fight. The Zęza, a moral, cultural and social place of longing with a strong appeal for action, plays a central role as an ideal and as real history of local self-determination. Iwona assimilates the lost place of longing of the Zęza in order to found her own business in spite of local resistance. The myths of the old Zęza bestow her with the necessary cultural imagination for her own snack bar "Fish at Iwona's". They raise her confidence in the future and permit cultural change in a place, where locals complain about social envy and mutual distrust, whilst they are subdued by tourism magnates.

Chan et al. (2016) observe similar processes of cultural adaptation in opposition to becoming subjected to gentrification process. They suggest the notion of self-gentrification to describe such local strategies " $[u]$ nder the threat of displacement to adopt a proactive approach to become the 'gentry' themselves. As such they are able to benefit from the positive aspects of gentrification whilst avoiding many of the negative effects, particularly displacement" (Chan et al. 2016: 1265). By positioning herself within the tourism discourse of longing in Sztynort and by appropriating the cultural blueprint of the old Zęza as a means of resistance against the port company, Iwona moves past the cultural dispossession of local residents through the sale of the area to an investor and reclaims her share of the socio-cultural capital and the heritage of the tourism destination.

\section{Complicit longings for local hospitality and rural life and compatible paths of gentrification}

Sailing novices, instructors as well as experienced sailors are all willing to consume Iwona's bar as part of Sztynort and of Masuria and thus to help create it as a new place of longing. One evening in July 2011 I accompany a group of sailing friends to Iwona's food truck, amongst them Radek, young founder of a tourism busi- 
ness with a sailing school from the region, Michał, my sailing instructor whom I already mentioned, the instructors Beata and Jarek and Magda and Kasia, two sailing students from Kraków. Together they are on a trip organised by Radek's sailing school. Busy behind the counter, Iwona and her parents give me a wink, when they recognize me, proudly, as I understand it. My sailing crew members order fish and chips, gherkins and choose bottled beer, which is advertised as local. They appreciate buying products of a local brewery here. I myself am surprised, as after one year of field research I hear the name of this brand for the first time, and I am sure that only very few locals know of it -localness is a work-in-progress in Masuria with its ruptured histories and uprooted populations, and tourism can help to set the scene. For the sailors, like for many people on a journey, the newly staged local flavor, here of craft beer, works part of the magic of the place.

Latest since Dean MacCannell's (1973) notion of "staged authenticity", questions of (staged) localness of tourism places have become a classic concern in tourism studies, including tourism anthropology (some examples include: Abram 1997; Boissevain 1996; Knudsen, Waade 2010). In the tavern of Sztynort, such branded localness seems to be a new product of the re-imagined, self-gentrified vision of the village. Tourists are the key protagonists of staging and performing the new local authenticity together with their rural hosts. Local brews allow them to partake of a distinctive place and thus promise a particularly "genuine", authentic experience. "In the meantime, we have become regulars here", Radek and the instructors tell me. With the beer, they support local business people in Masuria in the place of national or global businesses and can thus conform to their moral obligation to the region. They pay visit to Iwona's tavern with each group of their sailing students. They are relieved to see that finally there is an alternative to the port company, the activities of which they appreciate and take advantage of on the one hand, yet which they watch critically on the other hand. Their ideal is not the kind of uniform tourism which the port suggests, but a heterogenous, lively one, in which both the harbor and Iwona should have their place. Radek, like Iwona, is one of the few who returned to his home town in Masuria to create a professional future there. He has been watching the development in Sztynort for years and knows about the myth of the Zęza. He keeps repeating, that in the tourism business he often has to deal with dubious competitors from Warsaw. He is happy to see that it is possible to counteract the port company and that new local businesses are developing. The eatery fits in with his own vision of Masuria as a destination that is governed regionally and not from the outside and by outsiders alone.

Jarek and Beata are happy to leave the "all-inclusive" tourism package of the pleasure port with the "crowd of sailors" behind and the look behind the scenes of it from Iwona's place. As sailing instructors they would like to change the pleasure-oriented attitude of young sailing tourists. Rather than mere relaxation, sailing should involve discovery and cultural inquisitiveness. Both have been saving up for a round-the-world in their own boat. Iwona's fish and chips shop is attrac- 
tive to them, because they see their status as "true", good sailors threatened by the big number and incoherent values of sailing tourists and also because they are not satisfied within the business plan of the company that runs the port.

Before I can talk to Magda and Kasia, the two sailing novices, about their perception of the fish bar, they discuss their jobs and every-day life in Cracow. Both are in their early thirties and work in corporate marketing. They are looking back on extended work periods in the USA, about which they tell the sailors. The two are acquainted: their weekly highlight is the visit of a spa in the outskirts of Cracow, where they enjoy wellness treatments. They also want to get away from the every-day stress of their jobs in their sailing vacation. For the two female members of the new Polish leisure class, Iwona's small business is the icing on the cake of Sztynort, no contrast to the port area, but a perfect supplement. Enthusiastically the two describe to me the modern features of the port, the spacious, well-tended sanitary arrangements, the excellent organization of supply and its aesthetics. None of this, they have found out on their trip across the lakes, is self-evident in Masuria. At Iwona's they find what is yet missing to the reality of their tourist longings: the rural element.

"Here it really feels like in my grandparents' village", Magda rhapsodizes. Glossy magazines, romantic fiction and the media have brought about a revival of the rural, in which it often becomes exoticised as the desirable other - a trend to be also observed in other industrial nations. If the glorification of rural life is a continuum in the history of Poland, contemporary Polish experiences of neoliberal acceleration and digital interconnectedness seem to have called for a re-affirmation of this continuum, producing the rural as the shelter of "good life" or even paradise "sielsko", as a place of urban longing and as the promise of an unknown, lost authenticity - not unlike in many other places. While rural residents themselves can have mixed feelings about this imaginary that tends to close its eyes before the lived experience of making ends meet and of dealing with infrastructural weakness (cf. Wadle 2017), urban visitors associate rural life with remembrances from childhood so that their longing for the rural carries a nostalgic flavour. This rurality amnesia is unaware of violent pasts, uprooted identities, ethnic boundaries and social inequalities. Iwona's place thus fulfills Kasia's and Magda's longing for a more traditional, less perfect, more natural and simpler Poland, as it is depicted in Małgorzata Kalicińska’s (2006) novel Dom nad rozlewiskiem [The House by the Lake].

The story of Iwona, her family, and the sailing community, other visitors and other residents of Sztynort, is one of longue durée, the post-socialist struggle with council- and investor-led gentrifications and the process of opposition and self-gentrification stretch over the two generations of host and guests. Over time, Iwona's business has become a new place of encounter for individuals of various backgrounds, rural and urban ones, from different social settings and walks of education. In their encounter they create a domestic tourism community, which is 
established along the stakeholders' different, yet compatible quests for alternative local hospitality and their longing for a tourism supplement to the monopolistic port company. Even though the values of this community might be considered to be in moral opposition to the tourism proposed by the port company, or positions itself in contrast to it, this does, however, not mean that Iwona's bar as a new tourism sehnsuchtsort is incompatible with the pleasure port. On the contrary, it is not even perceived as a different and separate place in the tourism complex of Sztynort. In a way, it only exists because of the port, as a counter-site or a supplement to it. Following up on this emerging compatibility, it could be argued that Iwona's place, surpassing the many obstacles on the way, managed to become a compatible part in the multi-voiced story of touristic gentrification of the small tourism resort.

\section{Conclusion: Nostalgia for second chance, self- gentrification for an alternative future}

The yearning for one's place in the tourism resort of Sztynort and the accompanying dynamics and discourses recalibrates understandings of localness in a society "without traditions" (Łukowski 2005), aspirations and struggles in rural poststate farm environments, and the meaning of tourism sehnsuchtsorte for politics of place in Masuria. It seems that being able to draw on a local sehnsuchtsort that is meaningful to local and tourist communities, and on a history of the tourism encounter, in which accepted hospitality is foregrounded, is a valid basis for enacting localness and performing domestic social relations and the rural self on new terms.

In my contribution I have described longing as important driving force in processes of rediscovery or re-invention of places that communities feel to have lost. It is noteworthy that the site of the Zęza was not equally experienced as a lost place by all members of the sailing community, and that, as a consequence, no objective and definite "ending" of the tavern applied to all. Rather, the sense of place was reappropriated by different stakeholders and continued to exist in new commercial formats and for a diversifying community. While to some, like the young sailing instructor Michał, the "New Zęza" in its modernized form and in the new building has been perceived as an enrichment to the local tourism landscape in the continuity of the former sailors' tavern, I have more closely looked at those who have not been able or unwilling to identify with the new tourism modernity or simply have felt excluded from it. Unable to identify with the new place, they long for its predecessor, which they felt part of, for their prior selves as they unfolded in the tavern. This form of longing expresses feelings of loss, yet it also carries the potential for hope and action. By telling tales, engaging in discussions, and sharing video recordings about the old tavern, those who are mourning its loss 
keep the site alive as a counter narrative to the present. Throughout the text I have argued that the "Old Zęza" as a sehnsuchtsort carries the properties of a personal or communal resource that can be used by different stakeholders for their respective politics of place. Big investors, members of the tourism sailing community and also local sole traders have all mobilised this resource for their own visions of the future. The ethnographic discussion of the "Old Zęza" as a tourism sehnsuchtsort shows that neoliberal processes of transformation in Poland's tourism sector do not go unnoticed by the concerned tourism communities. With narratives of longing and the discussion of authenticity around the Zęza, sailors and locals actively criticize these processes of economic redistribution and new social orderings. As a place of longing the "Old Zęza" safeguards a set of values and a culture of experience which, as I have shown, can create cultural initiative and moral legitimation for local developments.

The fact that a small cultural community selects the bilge of all places, the most dirty part of the boat, to be their place of longing for over so many years strongly contrasts current tourism utopias in the shape of glossy, digitally upgraded, commercially and universally accepted paradises. Different from those transcendental abstractions of the paradisiacal or exotic known to us by their endless reproductions in the media and suggesting a longing seemingly inherent in all mankind, the "Old Zęza" remains culturally specific and therefore inapt for consumption by a global tourism industry and its customers. This site of yearning of longing rather represents an alternative draft to such universal places. In hindsight, the discussion of the sailing Tavern Zęza could be said to have introduced an empirical thinking about the metaphor of post-socialist liminality, which was notably coined by Michał Buchowski with his idea of post-socialist transformations as an "abyss of liminality" (2001) and, most recently and more biblically informed, as a "purgatory"(2018). The dirty bottom of the boat is maybe the antidote to "the false bottom" that every systemic change has according to Buchowski (2001: 115). It may thus be viewed as an ethnographic metaphor of post-socialist liminality and transgression, which, for different reasons has become mobilised a site of longing by different communities and individuals in a tourism context.

What is important to understand about the "Old Zęza" is that it is not a historic place watched through the spectacles of an exoticizing distance or ironic nostalgia, as we know them with other examples of post-Socialist tourism of longing (Stach 2019; Zinganel 2019) but an accepted benchmark for the evaluation of the present situation and a legitimate moral vision for the future, that needs to be taken seriously. In this context we also need to take into consideration that the place origins from a time the historic and moral evaluation of which has not yet been carved in stone. Moreover, it seems that imaginations of the old Zęza suggest the availability of a second chance, keeping the present moldable and flexible: By discursively descending back into the most liminal and least definite phase of contemporary Polish history in their imagination, the phase of early post-socialism, 
those who have felt excluded through processes of rural gentrification in tourism, may access a sense of being able to reset the present, and to come out with a new vision of transformation.

The story of Iwona, a dynamic entrepreneur, who does not leave the stage to her opponents, but fights for her place on the new map of the village in which she was born, challenges the dominant narratives about Masuria society. It offers an alternative narration about the children of state worker families, showing that marginalization need not follow the principle of social inheritance. The deep attachment and care that Iwona feels for her place strongly opposes the idea of a Masurian population without roots and suggests the central roles that tourism and the possibility of becoming hosts has played in crafting senses of local authority and sense of responsibility for place. Thirdly, the story of Iwona and her new enterprise challenges ideas of a growing unsurmountable divide between social classes in Poland and witnesses of some complicity between individuals of different backgrounds and of a compatibility of longings. The possibility of these counter narratives suggest that the developing of a more diversified perspective of tourism gentrification should be pursued further, as one that also accounts for the empowering and emancipating capacity of self-led gentrification processes.

\section{Postscriptum: Continuations}

The story of the Zęza continues. In the year 2019, the marina was sold to a new owner. In the first round of re-designing the area, the owners surprised the sailing community: They decided to re-open the "old" Zęza in its former location of the vault cellar, changing the wine bar back into a sailing tavern, where which live-music events could take place and spontaneous musical sessions with guitars and singing was encouraged. To recall the atmosphere of the "old" Zęza, the cellar was furnished with the iconic rustic, simple wooden benches and tables, that had coined the place in the past. The "new" Zęza was renamed and refurbished as a restaurant for the sailing community with a live concert venue. Both moves were largely welcomed among sailing tourists, in the residential village, and in the digital realm.

The new owners, a foreign corporation, had employed a new onsite manager who, having been raised in the area and working in tourism for his professional way, had excellent knowledge of the sailing community. The onsite manager was also a former informant to my research, had kept in the loop with my work and attended public presentations I gave in the area in 2015. So by the time the Old Zęza was being reintroduced, the ethnographic knowledge of the project you are reading about had started to travel and interact with local practice. Further developments will have to be observed ethnographically. 


\section{Bibliography}

Abram S.

1997 Performing Tourism in Rural France in: S. Abram, J. Waldren, D. Macleod (eds), Tourists and Tourism: Identifying People and Places, Oxford-New York, p. 29-49. Ahbe T.

2005 Ostalgie: Zum Umgang mit der DDR-Vergangenheit in den 1990er Jahren [Remembering the Past of the GDR in the 1990s] Erfurt.

Anderson B.

1983 Imagined Communities, London-New York.

Arkaraprasertkul N.

2018 Gentrification and Its Contentment: An anthropological Perspective on Housing, Heritage and Urban Social Change in Shanghai, "Urban Studies", vol. 55 (7), p. 15611578.

Bach J.

2014 Consuming Communism: Material Cultures of Nostalgia in Former East Germany in: O. Angé, D. Berliner (eds), Anthropology and Nostalgia, London-New York, p. 123-138.

Bachelard, G.

1994 (orig. 1958) The Poetics of Space, Boston.

Berdahl D.

1999 "(N)Ostalgie" for the Present: Memory, Longing, and East German Things, "Ethnos", vol. 64 (2), p. 192-211.

Boissevain J.

1996 Ritual, Tourism and Cultural Commodization in Malta: Culture by the Pound in:

T. Selwyn (ed.), The Tourist Image: Myth and Myth Making in Tourism, Chichester, p. 105-120.

Boym S.

2001 The Future of Nostalgia, New York.

Brown-Saracino J.

2007 Virtuous Marginality: Social Preservationists and the Selection of the Old-Timer, "Theory and Society", vol. 36 (5), p. 437-468.

2009 A Neighborhood That Never Changes: Gentrification, Social Preservation, and the Search for Authenticity, Chicago.

Buchowski M.

2001 Rethinking Transformation: An Anthropological Perspective on Post-Socialism, Poznań.

2006 The Specter of Orientalism in Europe: From Exotic Other to Stigmatized Brother, "Anthropological Quarterly", vol. 79 (3), p. 463-482.

2017 Czyściec. Antropologia neoliberalnego postsocjalizmu, Poznań.

Burachovič S.

2002 Gedanken zum sudetendeutschen Heimwehtourismus aus tschechischer Sicht [Thoughts about Sudeten German Nostalgic Tourism from a Czech Point of View] in: E. Fendl (ed.), Zur Ikonographie des Heimwehs [About the Ionography of Nostalgia], Freiburg, p. 223-244. 
Chrenka B., Ira V.

2011 Transformation of Tourist Landscapes in Mountain Areas: Case Studies from Slovakia, "Journal of Studies and Research in Human Geography", vol. 5 (2), p. 13-20.

Chrzanowski T.

2001 Kresy czyli obszary tęsknot [The Kresy or Places of Longing], Kraków.

Cynarski W., Cynarska E.

2009 Turystyka sentymentalna Polaków na Kresy Wschodnie [Sentimental Tourism of Polish People to the Eastern Borderland], "Ido - Ruch dla Kultury" [Movement for Culture], vol. 9 (8), p. 201-209.

Derek M.

2007 Od wioski rybackiej do turystycznej enklawy? Turystyka a rozwój lokalny na przykładzie Mikołajek [From Fishing Village to Tourism Enclave? Tourism and Local Development in the Example of Mikołajki], "Studia Regionalne i Lokalne" [Regional and Local Studies], vol. 28 (2), p. 112-127.

Fendl E.

1998 Reisen in die verlorene Vergangenheit. Überlegungen zum „Heimwehtourismus“ [Travels to a Lost Past: Thoughts about Tourism of Nostalgia], „Jahrbuch für deutsche und osteuropäische Volkskunde" [Yearbook for German and Estern European Ethnology], vol. 41 (16).

Gądecki J.

2017 I love NH: Gentryfikacja starej części Nowej Huty? Warszawa.

Ghodsee K.

2005 The Red Riviera: Gender, Tourism, and Postsocialism on the Black Sea, Durham, NC-London.

Gravari-Barbas M., Guinand S. (eds)

2017 Tourism and Gentrification in Contemporary Metropolises, London.

Grochocka A.

2015 Masuren. Vom Naturparadies zum Atlantis des Nordens. Funktion und Geschichte eines literarischen Mythos [Masuria: From Natural Paradise to Atlantis of the North. Function and History of a Literary Myth], Marburg.

Hann Ch.M.

2012 Transition, Tradition, and Nostalgia: Postsocialist Transformations in a Comparative Framework, "Collegium Antropologicum” vol. 36 (4), p. 1119-1128.

He S.

2007 State-sponsored Gentrification under Market Transition, the Case of Shanghai, "Urban Affairs Review", vol. 43 (2), p. 171-198.

Heady P., Miller L.L.G.

2006 Nostalgia and the Emotional Economy: A Comparative Look at Rural Russia in: M. Svašek (ed.), Postsocialism: Politics and Emotions in Central and Eastern Europe, New York, p. 35-52.

Herzfeld M.

2005 Cultural Intimacy: Social Poetics and the Nation State, New York-London.

Hines J.D.

2010 Rural Gentrification as Permanent Tourism: The Creation of the New West Archipelago as Post-industrial Cultural Space, "Environment and Planning D: Society and Space", vol. 28 (3), p. 509-525.

Hornstein S.

2011 Losing Site: Architecture, Memory, and Place, Farnham-Burlington. 
Jakoboczyk-Gryszkiewicz J., Sztybel-Boberek M., Wolaniuk A.

2017 Post-Socialist Gentrification Processes in Polish Cities, "European Spatial Research and Policy", vol. 24 (2), p. 145-166.

Kalicińska M.

2006 Dom nad rozlewiskiem, Poznań.

Knudsen B.T., Waade A.M. (eds)

2010 Re-investing Authenticity: People, Place, and Emotions, Clevedon.

Kossert A.

2009 Kalte Heimat: Die Geschichte der deutschen Vertriebenen nach 1945, München.

Kossert A.

2007 Ostpreußen: Geschichte und Mythos, München.

Kossert A.

2006 Masuren. Ostpreußens vergessener Süden, München.

Kuligowski W.

2019 How "Poland Entred Europe": The Motorway as a Space of Neoliberalism, "Transfers", vol. 9 (1), p. 1-19.

Łukowski W.

1998 Mazury. W poszukiwaniu wizerunku regionu?, Warszawa.

2002 Społeczne tworzenie ojczyzn: studium tożsamości mieszkańców Mazur, Warszawa. 2005 Die Inszenierung lokaler Identität in „traditionslosen“ Gesellschaften: das Beispiel Masuren in: U. Mai (ed.), Masuren: Trauma, Sehnsucht, leichtes Leben: zur Gefühlswelt einer Landschaft, Bielefeld, p. 141-174.

MacCannell D.

1973 Staged Authenticity: Arrangements of Social Space in Tourist Settings, "The American Journal of Sociology", vol. 79 (3), p. 589-603.

Macdonald S.

2013 Memorylands: Heritage and Identity in Europe Today, London-New York.

Mai U.

2005 „Das einfache Leben“: Zur Wahrnehmung der masurischen Landschaft unter Neusiedlern in: U. Mai (ed.), Masuren: Trauma, Sehnsucht, leichtes Leben: zur Gefühlswelt einer Landschaft, Bielefeld, p. 310-369.

Marcińczak S., Gentile M., Stępniak M.

2013 Paradoxes of (Post)Socialist Segregation: Metropolitan Sociospatial Divisions Under Socialism and after in Poland, “Urban Geography”, vol. 34 (3), p. 327-352.

Marcus G.E.

2011 Multi-Sited Ethnography: Five or Six Things I Know about It Now in: C. Coleman, P. von Hellermann (eds), Multi-Sited Ethnography Problems and Possibilities in the Translocation of Research Methods, New York-London, p. 16-34.

Martin K.

2009 Living Pasts: Contested Tourism Authenticities, "Annals of Tourism Research", vol. 37 (2), p. 537-554.

Meindl R.

2019 Heilsamer Schock? Die Konfrontation der deutschen „Heimwehtouristen“ mit ihren Sehnsuchtsorten in Ostmitteleuropa in: B. Hoenig, H. Wadle (eds), Eden für jeden? Sehnsuchtsorte in Mittel-und Osteuropa von 1945 bis zur Gegenwart, Göttingen, p. 63-84. 
Nadkarnyi M., Shevchenko O.

2014 The Politics of Nostalgia in the Aftermath of Socialism's Collapse: A Case for Comparative Analysis in: O. Angé, D. Berliner (eds), Anthropology and Nostalgia, LondonNew York, p. 61-96.

Ocejo R.E.

2011 The Early Gentrifier: Weaving a Nostalgia Narrative on the Lower East Side, "City \& Community", vol. 10 (3), p. 285-310.

2014 Upscaling Downtown: From Bowery Saloons to Cocktail Bars in New York City, Princeton-Oxford.

Palmberger M.

2008 Nostalgia Matters: Nostalgia for Yugoslavia as Potential Vision for a Better Future, "Sociologija", vol. L (4), p. 355-370.

Picard D.

2011 Tourism, Magic, Modernity: Cultivating the Human Garden, New York-Oxford. Piotrowski M.

1988 Interster - spółka ludzi aktywnych [Interster - Joint Venture of the Active], "Wiadomości Węgorzewskie”, vol. 190.

Rakowski T.

2009 Łowcy, zbieracze, praktycy niemocy. Etnografia człowieka zdegradowanego, Gdańsk.

Sakson A.

1990 Mazurzy - społeczność pogranicza, Poznań.

Salazar N., Graburn N. (eds)

2014 Tourism Imaginaries: Anthropological Approaches, New York-Oxford.

Sequera J., Nofre J.

2018 Shaken, not Stirred, "City", vol. 22 (5-6), p. 843-855.

Stach S.

2019 Urbanität und Nostalgie? Auf der Suche nach Entschleunigung in der städtetouristischen Vermarktung des „kommunistischen Erbes“ in: B. Hoenig, H. Wadle (eds), Eden für jeden? Sehnsuchtsorte in Mittel- und Osteuropa von 1945 bis zur Gegenwart, Göttingen, p. 281-208.

Szpak E.

2005 Między osiedla i zagrodą. Życie codzienne mieszkańców PGR-ów, Warszawa.

Tarkowska E.

2000a Bieda popegeerowska [Post-State Farm Poverty in Poland] in: E. Tarkowska (ed.), Zrozumieć biednego. O dawnej i obecnej biedzie w Polsce [Understanding the Poor. On former and contemporary poverty in Poland], Warszawa, p. 90-102.

2000b Teraźniejszość dawnych PGR-ów. Stare i nowe problemy społeczne [The present of Former State Farms in Poland] in: E. Tarkowska (ed.), Zrozumieć biednego. O dawnej i obecnej biedzie $w$ Polsce [Understanding the Poor. On former and contemporary poverty in Poland], Warszawa, p. 103-115.

Todorova M., Gille Z. (eds)

2010 Post-Communist Nostalgia, New York.

Traba R.

2003 Kraina tysiąca granic. Szkice o historii i pamięci [Land of the Thousand Borders: Essays on History and Remembrance], Olsztyn.

Urbańczyk A.

2013 Ale jednak żeglowaliśmy [Despite All We Sailed], Warszawa. 
Vail M.A.

2004 Right of Passage: Backpacker Subculture and the "Gentrification" of Tourism in Bolivia, New York.

Verdery K.

2003 The Vanishing Hectare: Property and Value in Postsocialist Transylvania, IthacaLondon.

Wakar A.

1971 Cztery Wieki Wegorzewa [400 Years of Wegorzewo], Olsztyn.

Wadle $\mathrm{H}$.

2017 Domestic Tourism Encounters in the Masurian Lake District: Multiple Tourism Moralities, Reversible Relationships, and Social Well-Being in Contemporary Poland, "Journal of Tourism and Cultural Change", vol. 15 (2), p. 136-151.

Wadle H., Verschaeve M.

2014 Tourism and Post-socialist Heterotopias: Eastern Europe as an Imagined Rural Past in: D. Picard, M.A. Di Giovine (eds), Tourism and the Power of Otherness. Seductions of Difference, , Bristol [etc.], p. 74-94.

Yurchak A.

2005 Everything Was Forever, Until It Was No More: The Last Soviet Generation, Berkeley.

Zajas K.

2009 Kresy skreślone, czyli o polskiej wielokulturowości [The lost Kresy or: About Polish Multiculturalism], „Wielogłos” [Polyphonic], nr 1-2 (5-6), p. 110-122.

Zinganel $\mathrm{M}$.

2019 Melancholie des (Ver-) Falls. Über die Lust des Wiederbereisens von Hotelruinen der sozialistischen Spätmoderne an der kroatischen Adriaküste in: B. Hoenig, H. Wadle (eds), Eden für jeden? Sehnsuchtsorte in Mittel- und Osteuropa von 1945 bis zur Gegenwart, Göttingen, p. 253-280.

\section{Newspaper articles}

Piotrowski M.

1988 Interster - spółka ludzi aktywnych [Interster - Business Group of the Active], "Wiadomości Węgorzewskie" [Węgorzewo News], vol. 190, no page.

1991 Sztynort skomunalizowany - papierowa wojna [Sztynort Now Belongs to the Community - Paper War], "Wiadomości Węgorzewskie" [Węgorzewo News, vol. 21 (33), p. 1, 3f.

C.J.

1992a Bój ostatni [The Last Battle], "Wiadomości Węgorzewskie" [Węgorzewo News], vol. 6 (49), p. 1.

1992b Sztynort: Brak zakończenia [Sztynort: No End in Sight], "Wiadomości Węgorzewskie", nr 7 (50), p. 1.

Dągowski I.

1997 Czy Węgorzewo bankrutuje? [Will Wegorzewo Be Bankrupt?], “Gazeta Giżycka”, vol. 20 (310), p. 6. 
Kwiatkowski D.

1996 Sztynort pełen marzeń [Sztynort Full of Dreams], “Gazeta Olsztynska”, $27^{\text {th }}-29^{\text {th }}$ Sept., p. 2 f. Łapo J.M.

1997 Ping-pong po sztynorcku, czyli inwestycja na wulkanie [Sztynorter Ping-Pong, or an Investment on the Volcano], "Gazeta Gizycka", vol. 7 (297), p. 4.

1999 Nie sprzedawać? [Do Not Sell?], “Węgorzewski Tydzień”, vol. 44 (437), p. $9 f$. n.n.

1995 Sztynort prawie sprzedane! [Sztynort sold!], “Gazeta Gizycka”, 10 (200), p. 2. n.n.

2000 Mieszkańcy walcza o przyzagrodowe działki. Protest odrzucony [Locals Fight for Their Courtyards: Protest Refused], "Gazeta Gizycka”, vol. 49 (494), p. 9.

Tomaszewski W.

1997 Austriackie gadanie. Sztynort znowu bez właściciela? [Sztynort...?], "Express Wieczorny", vol. 4, p. $10 f$.

The following websites and platforms were consulted for digital ethnography: campeteam.pl

zegluj.net

sailforum.pl

mazury.info.pl

gastronauci.pl

in Google-groups: <http://groups.google.com/group/pl.rec.zeglarstwo>; on the Video Platform youtube.com or on private blogs: blog.fafara.net 